\title{
Tree species and microhabitat affect forest bog spider fauna
}

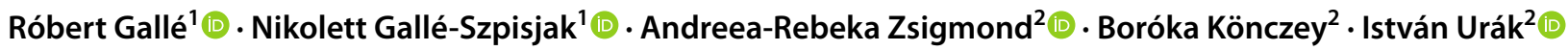

Received: 15 October 2020 / Revised: 21 December 2020 / Accepted: 16 January 2021 / Published online: 10 February 2021

(c) The Author(s) 2021

\begin{abstract}
Peat bogs are among the most threatened habitats in Central Europe. They are characterized by stagnant water with low $\mathrm{pH}$ and lower nutrient content compared to the surrounding habitats. The flora and fauna of peat bogs comprised of many habitat specialist and rare species. We explored the differences in spider fauna of European spruce and Scots pine forests. Furthermore, we assessed the effect of microhabitat diversity in the bog forests of the Poiana Stampei peat bog complex, Bucovina, Romania. We collected numerous rare and cold-adapted species. .We found a strong effect of forest type, presumably due to the different microclimatic conditions of the forests. European spruce forests had lower species richness of ground-dwelling fauna than Scots pine forests; however, we found contradictory results for vegetation-dwelling species richness. Hummocks had a more positive effect on the ground-dwelling spiders of Scots pine than in European spruce forests, presumably due to the more open structure of sphagnum hummocks than ground level. However, this effect was negative for vegetation dwellers. The cold-adapted species with restricted ranges are vulnerable to climate change, and bogs may serve as important micro-refugia for them. Central European bogs are isolated and highly threatened by anthropogenic activities, such as drainage, peat extraction, and eutrophication. The deterioration habitat quality of peat bogs will result in a significant loss in the regional species pool of the Carpathians.
\end{abstract}

Keywords Carpathians $\cdot$ European spruce $\cdot$ Hummock $\cdot$ Microclimate $\cdot$ Scots pine $\cdot$ Peat bog

\section{Introduction}

Heterogeneity of microhabitat structure is an inherent feature of habitats and is considered as an important driver of animal diversity (Tews et al. 2004). Structurally complex habitats may provide diverse food resources and refuges, and thus increase species diversity (McCoy and Bell 1991). Furthermore, more heterogeneous habitats are thought to be more resilient to disturbances (Bellone et al. 2017). Thus, habitat heterogeneity at multiple spatial scales has been revealed as key for biodiversity conservation (Benton et al. 2003; Moreno et al. 2016). However, the effects of habitat

Communicated by Claus Bässler.

Róbert Gallé

galle.robert@okologia.mta.hu

1 Institute of Ecology and Botany, Lendület Landscape and Conservation Ecology, ELKH Centre for Ecological Research, Alkotmány u. 2-4, Vácrátót 2163, Hungary

2 Department of Environmental Sciences, Sapientia Hungarian University of Transylvania, Calea Turzii 4, 400193 Cluj-Napoca, Romania heterogeneity vary considerably between taxonomic groups depending on whether structural heterogeneity is perceived as heterogeneity or habitat fragmentation (Tews et al. 2004).

Temperate forests harbour a high diversity of arthropods. The importance of fine-scale habitat heterogeneity on arthropod communities was explored by several studies in Europe (e.g. Hsieh and Linsenmair 2011; Kosulič et al. 2016; Šipoš et al. 2017). Habitat features and microhabitat parameters, such as decaying woody material, and shrubs are correlated with the distribution of species (e.g. Gallé et al. 2014; Ziesche and Roth 2013) and the functional diversity of their communities (Gallé et al. 2017).

Peat bogs are nutrient-poor habitats characterized by a high water table and low pH (Spitzer and Danks 2006). Their specific microclimate, acidity, and food scarcity act as an environmental filter and determine their unique, specialized flora and fauna with rare and threatened species (Kamayev 2012). Bog forests are common in the northern taiga zone, but very rare in the temperate climate zone, and they are usually located in drainless depressions. Peat bogs and bog forests are among the most sensitive and endangered habitats in Central Europe (Haase and Balckenhol 2015). 
Spiders are an abundant group of ground-dwelling as well as vegetation-dwelling arthropods and are among the most abundant predators of other arthropods, thus performing an ecologically important role in almost all of the terrestrial ecosystems (Wise 1995). Ground-dwelling spiders are mostly comprised of cursorial species that wander across diverse microhabitats in search of their prey. Whereas vegetation-dweller species, either web-builders or active hunters are more dependent on habitat structures that are necessary for web placement or constitute the substrate for foraging (Barton et al. 2017; Gollan et al. 2010).

Our study aims to demonstrate the differences between the spider fauna of Scots pine and European spruce bog forests and the effect of hummocks on the species composition of spiders. More specifically we hypothesized that (1) European spruce forests with close canopy have lower species richness than Scots pine forests with open canopy due to the colonization of open habitat species in the latter; and (2) hummocks have an effect on species composition of spider communities, and this effect is stronger for vegetationdwelling species.

\section{Materials and methods}

\section{Study sites and sampling}

Our study was conducted in the largest peat bog (Tinovul Mare Poiana Stampei) of the Eastern-Carpathians in Bucovina, Eastern-Romania, part of the Călimani National Park (N 47 17' 41"; E $\left.25^{\circ} 06^{\prime} 45^{\prime \prime}\right)$ with a total area of 695 ha (Fig. 1). The bog lies at the altitude of 900-1024 m asl. It is situated in the temperate continental climatic zone; however, the mean annual temperature is relatively low $\left(4.2{ }^{\circ} \mathrm{C}\right)$. The mean annual precipitation is circa $740 \mathrm{~mm}$ (Danu and Chifu 2007). The soil is acidic with a pH of 3.6-5 (Cazacu et al. 2018). Tinovul Mare Poiana Stampei is part of the Natura 2000 ecological network (ROSCI0247 Tinovul Mare Poiana Stampei), and it was included in the List of Wetlands of International Importance (Ramsar Site no. 2003) (Danu and Irimia 2009). The main tree species are Scots pine (Pinus sylvestris forma turfosa) and European spruce (Picea abies), both species form relatively homogeneous forests.

We selected 15 hummocks for sampling ground-dwelling spiders in each of the two forest types keeping a minimum distance of $30 \mathrm{~m}$ between them. We assessed the microclimatic differences using data loggers (Testo $176 \mathrm{H} 2$ ), two loggers were placed on top of separate, randomly selected hummocks and two loggers were placed on the ground near the focal hummock in both forest types.

At each sampling site, we used a pair of pitfall traps to survey spiders. One trap was placed on top of the hummocks, and the other on the ground level near the focal hummock (two forest types $\times 15$ hummocks $\times$ two positions $=60$ traps in total). The traps were plastic cups with a diameter of $8.5 \mathrm{~cm}$ filled with a 50:50 ethylene-glycol/water solution to which we added a few drops of detergent. To minimalize spatial autocorrelation, sampling sites were at least $40 \mathrm{~m}$ apart, and we kept five metres between the traps of the same pair. We performed our sampling in the frost-free period, traps were open for two months:14 June-21 August 2019 (emptied on 06 July 2019). For each pitfall trap, we pooled the data from the two collection periods.

Furthermore, we used a 'D-vac' suction sampler to survey vegetation-dwelling spiders. We conducted sampling on 06 July and 25 August 2019. We collected 10 samples from hummocks and 10 samples between hummocks (two forest types $\times 10$ hummocks $\times$ two positions $\times$ two periods $=80$ samples in total). Each sample consists of 10 subsamples. The 'D-vac' head was placed on the ground 10 times. Spiders caught with suction sampling were placed in 70:30 alcohol/water solution. All adult spider specimens were identified to species level using standard keys (Nentwig et al. 2019). Juvenile spiders cannot be identified precisely to species level, therefore we excluded them from further analyses. We listed species included in Red Lists of Central European Countries (Check Republic, Germany, Poland, and Carpathian Red list of spiders) to assess the conservation importance of the spider fauna ( ̌̌ezáč et al. 2015).

\section{Data analysis}

We used generalized linear models to determine the effect of forest type (Scots pine or European spruce) and sample position (top of hummock or ground) on the mean daily temperature, and minimum and maximum temperature. We determined the effect of forest type and sample position on species richness and activity density of spiders with generalized linear models. We calculated separate models for pitfall trap and D-vac data. We used the Poisson error term for species richness and negative binomial error term for activity density of spiders after checking for overdispersion of the data. For the D-vac data, sampling period was used as a random variable in the models.

The multivariate response of spider communities to forest type and sample position was studied with nonmetric multidimensional scaling (NMDS) based on a Bray-Curtis dissimilarity matrix. A Hellinger transformation was applied to the activity density data before the ordination. We tested the differences in spider species composition of Scots pine and European spruce forests and the effect of sample position with permutational multivariate analysis of variance (PERMANOVA) using a Bray-Curtis dissimilarity matrix with 4999 permutations and the "adonis" function in the "vegan" R package (Oksanen et al. 2016). We 
tested differences in multivariate dispersion of forest and sample position types using a multivariate homogeneity of group dispersion test (PERMDISP) with the "betadisper" function in "vegan". Both PERMANOVA and PERMDISP analyses were run with the Bray-Curtis distance metric and 4999 permutations. We applied the indicator value analysis (IndVal) to identify characteristic spider species of habitat types (Dufrêne and Legendre 1997). We calculated the IndVal value on the basis of the relative frequency and relative average abundance of the species. The statistical significance of the species indicator values was evaluated by a Monte Carlo procedure.

\section{Results}

Mean daily temperature and daily maximum temperature was higher in spruce forests than in pine forests $(\beta=1.11$, $p<0.001 ; \beta=7.32, p<0.001)$; however, daily minimum temperature was lower in spruce forests than in pine forests $(\beta=-2.27, p<0.001)$, indicating a more fluctuating temperature in spruce forests than in pine forests. Sample position did not have a significant effect on the temperature (Appendix 1).

We collected 1571 ground-dwelling spiders with pitfall traps, 1178 adults and 393 juveniles belonging to 40 species. Furthermore, we recorded a total number of 3646 vegetation-dwelling specimens from D-vac samples, 943 adults and 2703 juvenile spiders belonging to 53 species (Appendix 2). More than $35 \%$ (30 out of 78 species) of the collected species are listed in Central European Red Lists. Furthermore, Taranucnus carpaticus Gnelitsa, 2016 Zora distincta Kulczynski, 1915 were new to the Romanian spider fauna (Weiss and Urák 2000).

\section{Ground-dwelling spiders}

Hummocks had higher species richness than the ground level in Scots pine forests; however, this effect was weak in European spruce forests (Table 1; Fig. 2a). We found a

Fig. 1 Location of study site and the two sampled habitat types a Scots pine forest, $\mathbf{b}$ European spruce

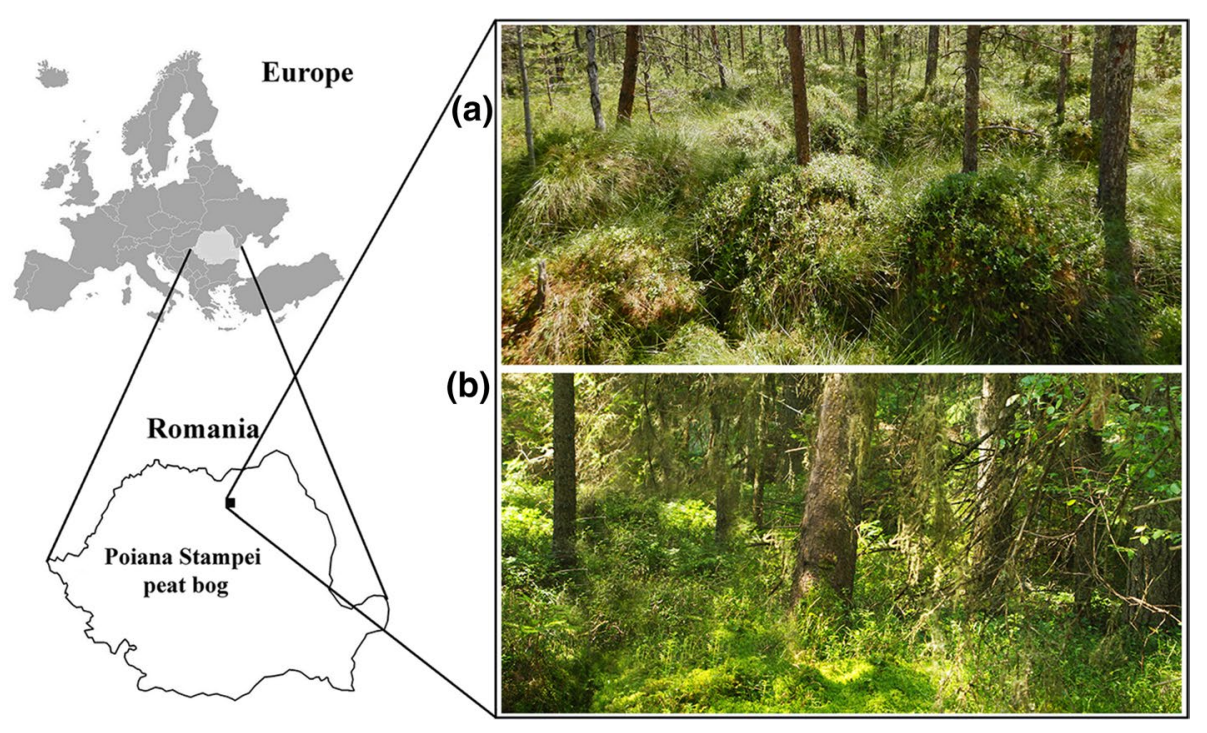

Table 1 Effect of forest type and microhabitat on species richness and total number of collected spiders according to generalized linear models. Parameter estimates $\pm 95 \%$ CI values and F-values are given in parenthesis

\begin{tabular}{lccc}
\hline & Forest type (scots pine/European spurce) & Microhabitat (hummock/ground) & Forest type: microhabitat \\
\hline Pitfall traps & & & \\
Species richness $^{\alpha}$ & $-0.836 \pm 0.315(-5.037)^{* * * *}$ & $-0.613 \pm 0.298(-3.981)^{* * *}$ & $0.756 \pm 0.477(3.097)^{* *}$ \\
Abundance $^{\beta}$ & $-0.917 \pm 0.365(-4.941)^{* * *}$ & $0.598 \pm 0.337(3.483)^{* * *}$ & $0.068 \pm 0.500(0.271)$ \\
D-vac samples & & & \\
Species richness $^{\alpha}$ & $-0.773 \pm 0.287(-5.196)^{* * *}$ & $0.342 \pm 0.311(2.131)^{*}$ & $-0.543 \pm 0.397(-2.670)^{* *}$ \\
Abundance $^{\beta}$ & $-0.491 \pm 0.197(-4.900)^{* * *}$ & $-0.140 \pm 0.192(-1.430)$ & $-0.128 \pm 0.281(-0.894)$ \\
\hline
\end{tabular}

${ }^{\alpha}$ Models fitted with Poisson error term

${ }^{\beta}$ Models fitted with negative binomial error term

Significance levels: $*:<0.05, * *:<0.01, * * *:<0.001$ 
Fig. 2 Effect of forest type and microhabitat on the spider fauna. Light grey bars: hummocks, dark grey bars: ground level. a Species richness of ground-dwelling spiders, $\mathbf{b}$ abundance of ground-dwelling spiders, $\mathbf{c}$ species richness of vegetation-dwelling spiders, $\mathbf{d}$ abundance of vegetation-dwelling spiders
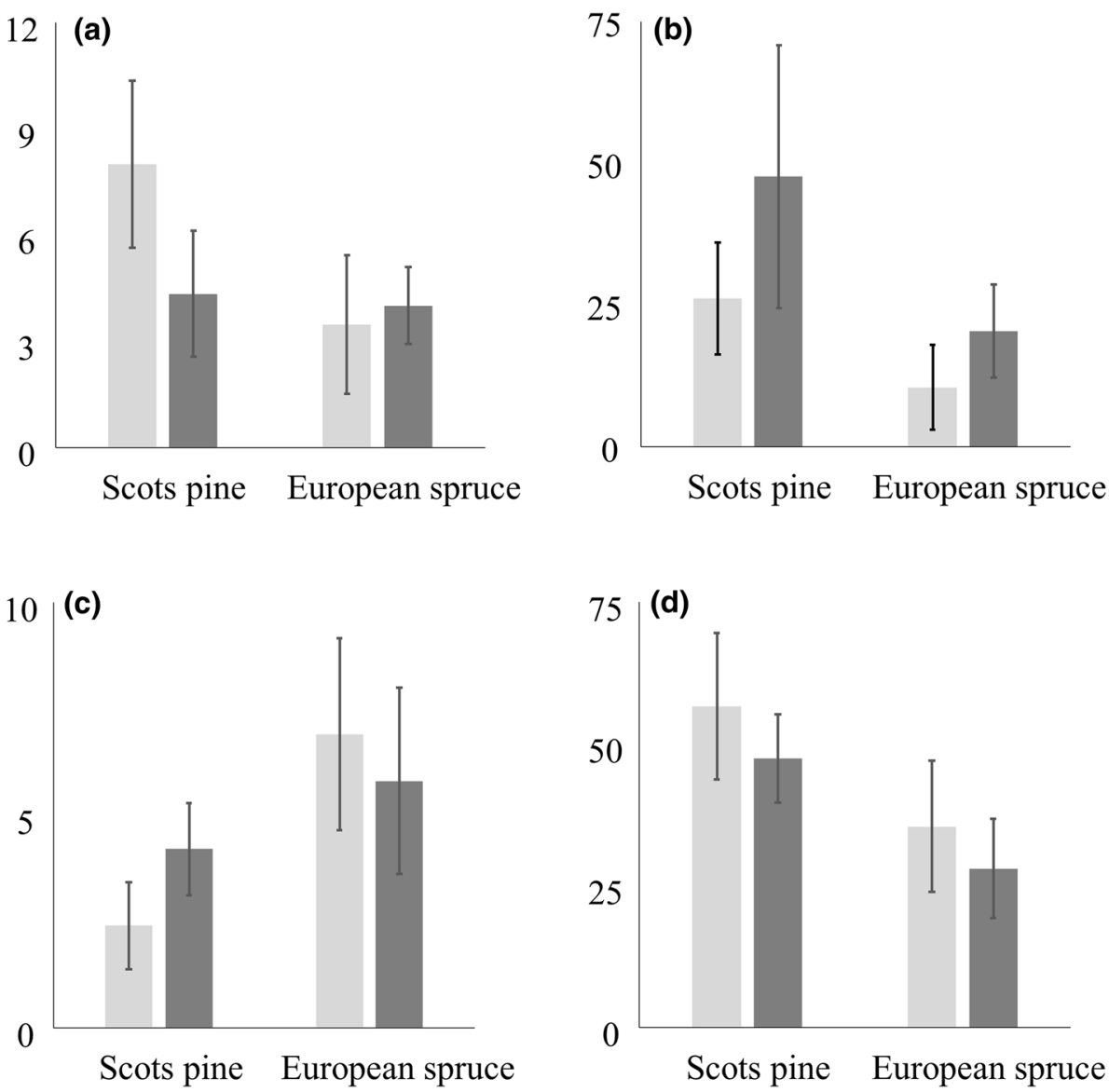

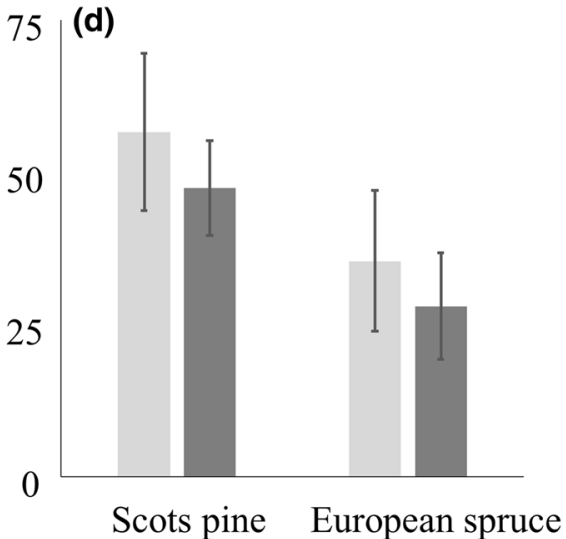

higher abundance of spiders in Sots pine than in European spruce forests, and lower abundances on hummocks than on the ground level (Table 1; Fig. 2b).

We found a significant effect of microhabitat $(F=9.965$, $\left.R^{2}=0.099, p<0.001\right)$, forest type $\left(F=27.271, R^{2}=0.272\right.$, $p<0.001)$, and their interaction $\left(F=8.001 ; R^{2}=0.0798\right.$, $p<0.001)$ on species composition according to the PERMANOVA model. We found higher overlap between the community composition of hummocks and ground level in
Scots pine than in European spruce forests (Fig. 3a). Furthermore, PERMDISP test showed that dissimilarity due to species composition did not differ for Scots pine and European spruce forests $(F=0.123, p=0.72)$; however, hummocks had greater variation than the ground level $(F=7.079$, $p=0.014)$. We identified 12 significant indicator species, 8 species for hummocks 2 species of ground level of European spruce, 1 species for hummocks 1 species of ground level of Scots pine.
Fig. 3 NMDS ordination plot of spider communities. a Grounddwelling spiders; $\mathbf{b}$ vegetation dwellers. Circles: Scots pine forests, triangles: European spruce forests, open symbols: hummocks, dark symbols ground level
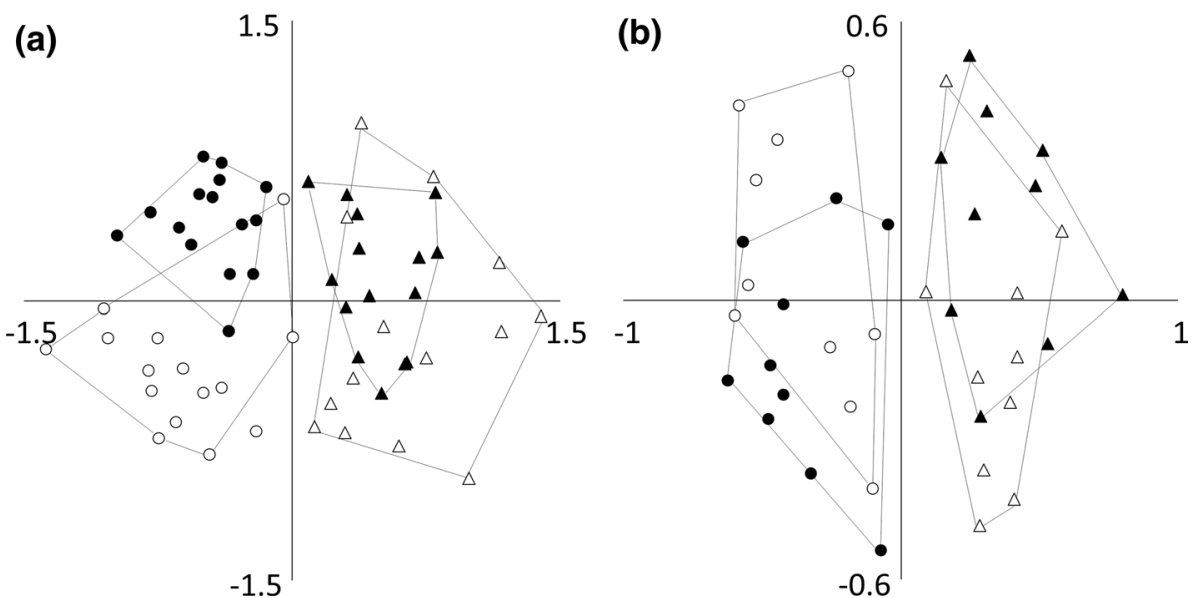


\section{Vegetation-dwelling spider}

Hummocks had lower species richness than the ground level in Scots pine forests; however, species richness was higher on hummocks than on the ground level in European spruce forests (Table 1; Fig. 2c). Spider abundances were higher in Sots pine than in European spruce forests (Table 1; Fig. 2d).

Forest type had a strong effect on the species composition of spiders (Fig. $3 b ; F=22.302, R^{2}=0.344, p<0.001$ ). However, microhabitat and the interaction between microhabitat and forest type had a significant, but relatively weak effect on the species composition $\left(F=3.11, R^{2}=0.048, p=0.016\right.$; $F=3.294, R^{2}=0.050, p=0.013$, respectively) according to the PERMANOVA. Dispersion analysis indicated withingroup dispersion did not differ significantly between Scots pine and European spruce forests $(F=4.083, p=0.055)$, furthermore, hummock and ground-level samples also had similar dispersion $(F=0.245, p=0.623)$. We identified 11 significant indicator species, 3 species of ground level of European spruce, 6 species for hummocks 2 species of ground level of Scots pine.

\section{Discussion}

In this study, we aimed to assess the effect of forest tree species and microhabitat on the spider fauna of bog forests. Following our hypothesis (1), European spruce forests had lower species richness of ground-dwelling fauna than Scots pine forests; however, we found contradictory results for vegetation-dwelling species richness. Our supporting hypothesis was that (2) hummocks, and the ground level had different species compositions of ground-dwelling spider communities; however, this effect was weaker for vegetation-dwelling species.

Shading and moisture conditions are the most important environmental factors for spiders (Entling et al. 2007). Bog forests are partly shaded to shaded with wet conditions. Ziesche and Roth (2008) and Černecká et al. (2020) also found that canopy openness has an important effect on spider species richness and activity density of the forest floor. Canopy affects light penetration, which in turn influences the ground and lower vegetation layers, and also modifies temperature and moisture conditions (Lindh and Muir 2004; Oxbrough et al. 2012).

In general, the temperature within a bog can be several degrees lower than the temperature of the surrounding terrain outside of the bog (Spitzer and Danks 2006). Furthermore, we found that microclimatic conditions vary between forests of different tree species, with more stable temperatures in European spruce forests than in Scots pine forest, presumably due to the open canopy of the latter. European spruce forests maintained a temperate microclimate due to lower solar transmission during the day and the thermal insulation provided by thick canopy during the night (Weng et al. 2007; Ingle et al. 2020). Temperature differences may affect the species composition of spiders. Kamayev (2012) also emphasized the effect of temperature regime and humidity of the soil in shaping spider assemblages of bog forests. The relatively open canopy of Scots pine forests may support higher diversity of understory vegetation (Nilsson et al. 2008; Oxbrough et al. 2012) and in turn a higher spider diversity (Docherty and Leather 1997). Presumably, forest structure and microclimate have a higher relative importance in shaping spider community composition than the effect of tree species per se (Vehviläinen et al. 2008; Ziesche and Roth 2008).

Hummocks form a separate microhabitat. The ground level is covered by stagnant water for a long period of the year (from autumn until early summer), and hummocks form a drier microhabitat even when the stagnant water disappeared (Stańska et al. 2016). The loose arrangement of the Sphagnum branches below the surface has a very high waterholding capacity and maintain stable moisture conditions throughout the year (Kajak et al. 2000). This may affect the temperature (Van der Molen and Wijmstra 1994); however, we did not find significant differences between the temperature of hummocks and the ground level. The structures of hummocks are more complex due to the thickness of the Sphagnum layer; thus, hummocks and may have a higher number of spider species living on the surface and within the moss layer than on the ground level (Koponen 2004). We found that variation in species composition of ground-dwelling spiders was higher on hummocks than on the ground level, indicating a high diversity of hummocks. We also found a higher number of ground-dwelling spider species and lower abundance on hummocks than on the ground level in Scots pine forests presumably due to the more complex structure of hummocks than the ground level. However, this pattern was the opposite for vegetation-dweller species of Scots pine forests.

Peat bogs are relatively common and widespread worldwide. Although their overall surface area is small, cca 3\%, they have a key role in carbon storage (Joosten and Clarke 2002; Urák et al. 2017) and harbour a disproportionately high number of specialist species (Gajdos et al. 2016; Gallé et al. 2019). This distinct arthropod community of bog forests have numerous, mainly cold-adapted arthropod species that significantly contribute to the regional species richness (Sławska et al. 2017). Scott et al. (2006) found 
that the richness of specialist spider species can serve as a surrogate for the conservation value of the invertebrate fauna of bogs. We collected 30 rare spider species with high conservation importance and two new species to the Romanian fauna, indicating a high natural value of Poiana Stampei peat bog. This is in line with several studies of the spider fauna Eastern Carpathian peat bogs emphasizing the unique nature conservation value of peat bogs (e.g. Gallé and Urák 2002, 2006; Gallé et al. 2019, Samu and Urák 2014). Our results show that the patchy microhabitat structure further increases the spider diversity of bog forests.

The cold-adapted species with restricted ranges are vulnerable to climate change, and bogs may serve as important micro-refugia for them (Ohlemüller et al. 2008; Gallé et al. 2019). Central European bogs are highly threatened by anthropogenic activities, such as drainage, peat extraction, and eutrophication (Haase and Balckenhol 2015). Changes in peat bog hydrology and soil properties negatively affect the species composition of peat bog flora and fauna (Brigić et al. 2017). Furthermore, they are highly isolated habitats, and this isolation increases as bog habitats degraded. The decay of peat bogs will result in a significant loss in the regional species pool. Biodiversity conservation is key for the long-term sustainability of peat bog ecosystems; conservation strategies should promote abandonment or very extensive management practices aimed at maintaining habitat and microhabitat diversity, hence supporting high biodiversity. The regular monitoring of the stenotopic peat bog flora and fauna should become a target for Romanian nature protection as it is crucial to initiate early restoration efforts to avoid an irreversible habitat degradation of small and isolated peat bogs.

\section{Appendix 1}

See Fig. 4.
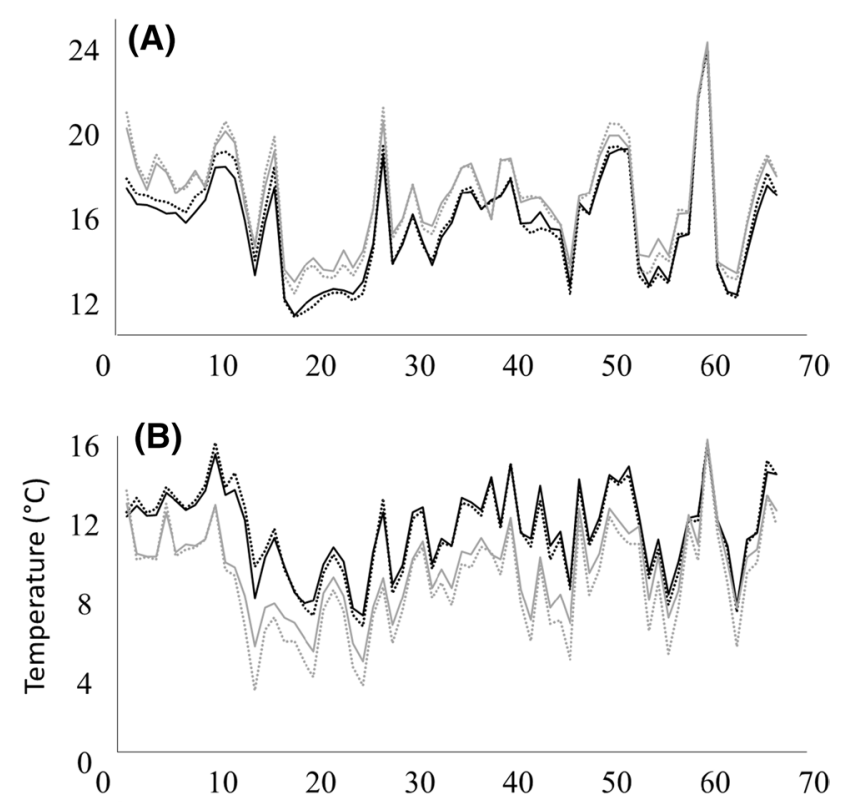

(C)

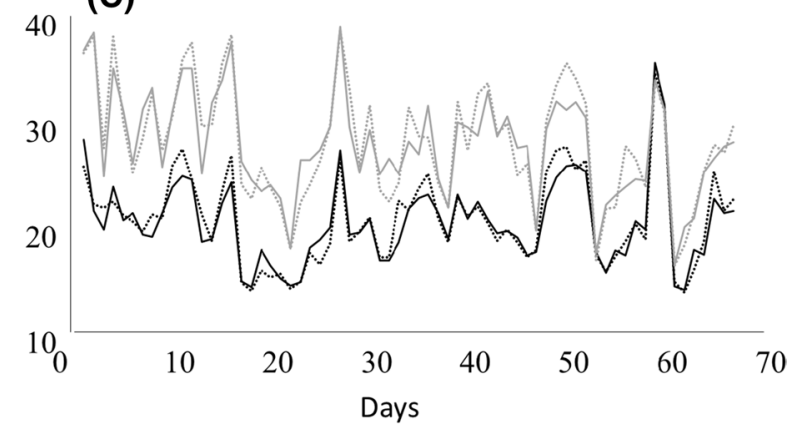

Fig. 4 Temperature profile of European spruce (black) and Scots pine (grey) forests. Hummocks are indicated with dotted line and ground level with solid line. a Mean daily temperatures, $\mathbf{b}$ daily minimum values and $\mathbf{c}$ daily maximum values

\section{Appendix 2}

See Table 2. 
Table 2 List of collected species

\begin{tabular}{|c|c|c|c|c|}
\hline \multirow[t]{2}{*}{ Pitfall trap samples } & \multicolumn{2}{|c|}{ European spruce } & \multicolumn{2}{|l|}{ Scots pine } \\
\hline & Hummock & Ground & Hummock & Ground \\
\hline Agroeca brunnea (Blackwall, 1833) & 3 & 0 & 3 & 0 \\
\hline Araneus marmoreus Clerck, 1757 & 0 & 0 & 1 & 0 \\
\hline Callobius claustrarius (Hahn, 1833) & 0 & 3 & 46 & 39 \\
\hline Centromerus arcanus (O. P.-Cambridge, 1873) & 0 & 1 & 0 & 0 \\
\hline Coelotes terrestris (Wider, 1834) & 20 & 6 & 13 & 21 \\
\hline Cybaeus angustiarum L. Koch, 1868 & 4 & 5 & 24 & 112 \\
\hline Dicymbium tibiale (Blackwall, 1836) & 3 & 4 & 3 & 5 \\
\hline Diplostyla concolor (Wider, 1834) & 0 & 0 & 0 & 1 \\
\hline Drassodes pubescens (Thorell, 1856) & 1 & 0 & 0 & 0 \\
\hline Ero furcata (Villers, 1789) & 0 & 0 & 1 & 1 \\
\hline Euryopis flavomaculata (C. L. Koch, 1836) & 1 & 0 & 0 & 0 \\
\hline Macrargus rufus (Wider, 1834) & 1 & 0 & 0 & 1 \\
\hline Maso sundevalli (Westring, 1851) & 1 & 0 & 0 & 0 \\
\hline Metellina merianae (Scopoli, 1763) & 0 & 1 & 0 & 0 \\
\hline Micaria pulicaria (Sundevall, 1831) & 1 & 0 & 0 & 0 \\
\hline Micrargus herbigradus (Blackwall, 1854) & 0 & 0 & 1 & 3 \\
\hline Neon reticulatus (Blackwall, 1853) & 3 & 2 & 0 & 0 \\
\hline Neriene radiata (Walckenaer, 1841) & 8 & 1 & 1 & 0 \\
\hline Ozyptila trux (Blackwall, 1846) & 16 & 1 & 1 & 0 \\
\hline Pardosa lugubris (Walckenaer, 1802) & 0 & 1 & 0 & 0 \\
\hline Pardosa spider & 1 & 0 & 0 & 0 \\
\hline Pardosa riparia (C. L. Koch, 1833) & 10 & 2 & 0 & 0 \\
\hline Phrurolithus festivus (C. L. Koch, 1835) & 6 & 3 & 0 & 0 \\
\hline Piratula hygrophila (Thorell, 1872) & 34 & 167 & 8 & 52 \\
\hline Piratula uliginosaŁ(Thorell, 1856) & 41 & 382 & 0 & 5 \\
\hline Pocadicnemis pumila (Blackwall, 1841) & 1 & 1 & 0 & 0 \\
\hline Stemonyphantes lineatus (Linnaeus, 1758) & 0 & 0 & 1 & 0 \\
\hline Taranucnus carpaticus Gnelitsa, 2016 & 3 & 4 & 1 & 1 \\
\hline Tenuiphantes alacris (Blackwall, 1853) & 0 & 0 & 6 & 7 \\
\hline Tenuiphantes cristatus (Menge, 1866) & 2 & 1 & 1 & 0 \\
\hline Trochosa spinipalpis (F. O. P.-Cambridge, 1895) & 17 & 3 & 0 & 0 \\
\hline Walckenaeria atrotibialis O. P.-Cambridge, 1878 & 1 & 1 & 5 & 1 \\
\hline Walckenaeria cucullata (C. L. Koch, 1836) & 7 & 3 & 0 & 0 \\
\hline Walckenaeria furcillata (Menge, 1869) & 2 & 0 & 0 & 0 \\
\hline Walckenaeria mitrata (Menge, 1868) & 1 & 0 & 0 & 0 \\
\hline Zelotes clivicola (L. Koch, 1870) & 3 & 0 & 0 & 0 \\
\hline Zelotes latreillei (Simon, 1878) & 3 & 0 & 0 & 0 \\
\hline Zora distincta Kulczynski, 1915 & 11 & 0 & 0 & 0 \\
\hline Zora silvestris Kulczynski, 1897 & 5 & 0 & 0 & 0 \\
\hline Zora spinimana (Sundevall, 1833) & 9 & 1 & 0 & 1 \\
\hline \multirow[t]{2}{*}{ D-vac samples } & \multicolumn{2}{|c|}{ European spruce } & \multicolumn{2}{|l|}{ Scots pine } \\
\hline & Hummock & Ground & Hummock & Ground \\
\hline Anguliphantes tripartitus (Miller \& Svaton, 1978) & 0 & 0 & 2 & 1 \\
\hline Centromerus arcanus (O. P.-Cambridge, 1873) & 10 & 11 & 38 & 17 \\
\hline Centromerus pabulator (O. P.-Cambridge, 1875) & 0 & 0 & 0 & 5 \\
\hline Centromerus silvicola (Kulczynski, 1887) & 0 & 0 & 0 & 1 \\
\hline Ceratinella brevis (Wider, 1834) & 1 & 0 & 3 & 3 \\
\hline
\end{tabular}


Table 2 (continued)

$$
\text { D-vac samples }
$$

\section{European spruce}

Hummock
Clubiona subsultans Thorell, 1875

Cryphoeca silvicola (C. L. Koch, 1834)

Cybaeus angustiarum L. Koch, 1868

Cyclosa conica (Pallas, 1772)

Dicymbium tibiale (Blackwall, 1836)

Ero furcata (Villers, 1789)

Evarcha falcata (Clerck, 1757)

Gonatium rubellum (Blackwall, 1841)

Gongylidiellum murcidum Simon, 1884

Hahnia pusilla C. L. Koch, 1841

Kaestneria pullata (O. P.-Cambridge, 1863)

Lepthyphantes nodifer Simon, 1884

Macrargus rufus (Wider, 1834)

Mansuphantes arciger (Kulczynski, 1882)

Maso sundevalli (Westring, 1851)

Mecopisthes silus (O. P.-Cambridge, 1872)

Megalepthyphantes nebulosus (Sundevall, 1830)

Metellina mengei (Blackwall, 1870)

Micrargus apertus (O. P.-Cambridge, 1871)

Micrargus herbigradus (Blackwall, 1854)

Micrommata virescens (Clerck, 1757)

Minyriolus pusillus (Wider, 1834)

Neon reticulatus (Blackwall, 1853)

Notioscopus sarcinatus (O. P.-Cambridge, 1872)

Ozyptila trux (Blackwall, 1846)

Pelecopsis elongata (Wider, 1834)

Phrurolithus festivus (C. L. Koch, 1835)

Piratula hygrophila (Thorell, 1872)

Piratula uliginosat'(Thorell, 1856)

Pocadicnemis pumila (Blackwall, 1841)

Sintula corniger (Blackwall, 1856)

Stemonyphantes lineatus (Linnaeus, 1758)

Talavera aperta (Miller, 1971)

Talavera parvistyla Logunov \& Kronestedt, 2003

Tallusia experta (O. P.-Cambridge, 1871)

Taranucnus bihari Fage, 1931

Tenuiphantes alacris (Blackwall, 1853)

Tenuiphantes cristatus (Menge, 1866)

Tenuiphantes mengei (Kulczynski, 1887)

Tenuiphantes tenebricola (Wider, 1834)

Tenuiphantes tenuis (Blackwall, 1852)

Trochosa spinipalpis (F. O. P.-Cambridge, 1895)

Walckenaeria cucullata (C. L. Koch, 1836)

Walckenaeria cuspidata Blackwall, 1833

Walckenaeria mitrata (Menge, 1868)

Xysticus audax (Schrank, 1803)

Zora distincta Kulczynski, 1915

Zora spinimana (Sundevall, 1833)

\section{0}

0

0

0

0

0

5

2

0

6

0

0

0

0

0

0

0

0

1

1

0

2

8

0

3

0

1

1

1

4

13

0

0

0

0

0

0

95

0

1

0

0

0

0

0

1

0

3

\begin{tabular}{|c|c|c|}
\hline 0 & 0 & 1 \\
\hline 0 & 23 & 7 \\
\hline 0 & 1 & 2 \\
\hline 0 & 1 & 0 \\
\hline 3 & 13 & 8 \\
\hline 0 & 0 & 4 \\
\hline 6 & 1 & 0 \\
\hline 7 & 3 & 2 \\
\hline 0 & 1 & 0 \\
\hline 14 & 0 & 0 \\
\hline 1 & 0 & 0 \\
\hline 0 & 44 & 12 \\
\hline 2 & 1 & 4 \\
\hline 3 & 1 & 0 \\
\hline 0 & 13 & 4 \\
\hline 0 & 3 & 0 \\
\hline 0 & 0 & 1 \\
\hline 0 & 0 & 1 \\
\hline 2 & 1 & 3 \\
\hline 0 & 4 & 1 \\
\hline 1 & 0 & 0 \\
\hline 1 & 23 & 45 \\
\hline 1 & 3 & 1 \\
\hline 26 & 0 & 0 \\
\hline 2 & 7 & 0 \\
\hline 0 & 3 & 0 \\
\hline 0 & 0 & 0 \\
\hline 2 & 0 & 0 \\
\hline 1 & 0 & 0 \\
\hline 9 & 0 & 3 \\
\hline 7 & 25 & 7 \\
\hline 0 & 2 & 2 \\
\hline 0 & 0 & 1 \\
\hline 1 & 0 & 0 \\
\hline 1 & 0 & 0 \\
\hline 0 & 0 & 2 \\
\hline 20 & 34 & 15 \\
\hline 185 & 10 & 18 \\
\hline 1 & 0 & 0 \\
\hline 0 & 0 & 2 \\
\hline 1 & 0 & 0 \\
\hline 0 & 1 & 0 \\
\hline 2 & 4 & 3 \\
\hline 0 & 0 & 1 \\
\hline 0 & 1 & 2 \\
\hline 0 & 2 & 1 \\
\hline 2 & 2 & 4 \\
\hline 5 & 10 & 3 \\
\hline
\end{tabular}




\section{Appendix 3}

See Table 3.

Table 3 Spider species listed in Central European Red Lists (Řezáč et al. 2015)

\begin{tabular}{|c|c|c|c|c|}
\hline Spider species & Czech republic & $\begin{array}{l}\text { Carpathian } \\
\text { red list }\end{array}$ & Germany & Poland \\
\hline Agyneta conigera (O.P.-Cambridge, 1863) & & LC & & \\
\hline Anguliphantes tripartitus (Miller \& Svatoň, 1978) & & $\mathrm{LC}$ & & \\
\hline Araneus alsine (Walckenaer, 1802) & VU & & $\mathrm{LC}$ & \\
\hline Centromerus silvicola (Kulczyński, 1887) & & VU & & DD \\
\hline Clubiona subsultans Thorell, 1875 & $\mathrm{LC}$ & & & \\
\hline Dicymbium tibiale (Blackwall, 1836) & $\mathrm{LC}$ & & & \\
\hline Dolomedes fimbriatus (Clerck, 1757) & VU & & $\mathrm{LC}$ & \\
\hline Drassodes pubescens (Thorell, 1856) & & & & VU \\
\hline
\end{tabular}

Gongylidiellum murcidum Simon, 1884

Hahnia pusilla C.L.Koch, 1841

Kaestneria pullata (O.P.-Cambridge, 1863)

LC

Lasaeola tristis (Hahn, 1833)

Lepthyphantes nodifer Simon, 1884

Mansuphantes arciger (Kulczyński, 1882)

Mecopisthes silus (O.P.-Cambridge, 1872)

Metopobactrus prominulus (O.P.-Cambridge, 1872)

Micaria pulicaria (Sundevall, 1831)

Micrargus apertus (O.P.-Cambridge, 1871)

Notioscopus sarcinatus (O.P.-Cambridge, 1872)

Pardosa lugubris (Walckenaer, 1802)

Pelecopsis elongata (Wider, 1834)

Pirata uliginosus (Thorell, 1856)

Piratula hygrophila (Thorell, 1872)

Sibianor aurocinctus (Ohlert, 1865)

Sintula corniger (Blackwall, 1856)

Talavera aperta Miller, 1971

Trochosa spinipalpis (F.O.P.-Cambridge, 1895)

Walckenaeria mitrata (Menge, 1868)

Zelotes clivicola (L.Koch, 1870)

Zora distincta Kulczyński, 1915

VU

VU

VU

LC

LC

LC

LC

VU

LC

VU

LC

\section{LC}

$\mathrm{LC}$

LC

LC

LC

LC

LC 


\section{Appendix 4}

See Table 4.

Table 4 List of significant indicator species

\begin{tabular}{|c|c|c|c|}
\hline Pitfall trap samples & Habitat & IndVal & $p$ \\
\hline Neriene radiata Walckenaer 1841 & European spruce, hummock & 0.26 & 0.013 \\
\hline Pardosa riparia C L Koch 1833 & European spruce, hummock & 0.50 & $<0.001$ \\
\hline Phrurolithus festivus C L Koch 1835 & European spruce, hummock & 0.17 & 0.083 \\
\hline Trochosa spinipalpis F O P Cambridge 1895 & European spruce, hummock & 0.51 & $<0.001$ \\
\hline Walckenaeria cucullata C L Koch 1836 & European spruce, hummock & 0.32 & 0.003 \\
\hline Zora distincta Kulczyski 1915 & European spruce, hummock & 0.46 & $<0.001$ \\
\hline Zora silvestris Kulczynski 1897 & European spruce, hummock & 0.26 & 0.011 \\
\hline Zora spinimana Sundevall 1833 & European spruce, hummock & 0.27 & 0.011 \\
\hline Piratula hygrophilaThorell 1872 & European spruce, ground & 0.63 & $<0.001$ \\
\hline Piratula uliginosa Thorell 1856 & European spruce, ground & 0.89 & $<0.001$ \\
\hline Callobius claustrarius Hahn 1833 & Scots pine, hummock & 0.38 & 0.005 \\
\hline Cybaeus angustiarum L Koch 1868 & Scots pine, ground & 0.76 & $<0.001$ \\
\hline D-vac samples & Habitat & IndVal & $p$ \\
\hline Hahnia pusilla C L Koch 1841 & European spruce, ground & 0.42 & 0.016 \\
\hline Notioscopus sarcinatus O P Cambridge 1872 & European spruce, ground & 0.9 & $<0.001$ \\
\hline Tenuiphantes cristatus Menge 1866 & European spruce, ground & 0.54 & $<0.001$ \\
\hline Centromerus arcanus O P Cambridge 1873 & Scots pine, hummock & 0.45 & 0.008 \\
\hline Cryphoeca silvicola C L Koch 1834 & Scots pine, hummock & 0.69 & $<0.001$ \\
\hline Dicymbium tibiale Blackwall 1836 & Scots pine, hummock & 0.37 & 0.019 \\
\hline Lepthyphantes nodifer Simon 1884 & Scots pine, hummock & 0.78 & $<0.001$ \\
\hline Maso sundevalli Westring 1851 & Scots pine, hummock & 0.38 & 0.021 \\
\hline Tenuiphantes alacris Blackwall 1853 & Scots pine, hummock & 0.39 & 0.024 \\
\hline Ero furcata Villers 1789 & Scots pine, ground & 0.30 & 0.047 \\
\hline Minyriolus pusillus Wider 1834 & Scots pine, ground & 0.63 & $<0.001$ \\
\hline
\end{tabular}


Acknowledgements This study was financially supported by the Domus Hungarica Scientiarum et Artium research grant, in the joint programme of the Hungarian Ministry of Education and Culture and the Hungarian Academy of Sciences. RG was supported by the Janos Bolyai Research Scholarship of the Hungarian Academy of Sciences.

Funding Open Access funding provided by ELKH Centre for Ecological Research.

Open Access This article is licensed under a Creative Commons Attribution 4.0 International License, which permits use, sharing, adaptation, distribution and reproduction in any medium or format, as long as you give appropriate credit to the original author(s) and the source, provide a link to the Creative Commons licence, and indicate if changes were made. The images or other third party material in this article are included in the article's Creative Commons licence, unless indicated otherwise in a credit line to the material. If material is not included in the article's Creative Commons licence and your intended use is not permitted by statutory regulation or exceeds the permitted use, you will need to obtain permission directly from the copyright holder. To view a copy of this licence, visit http://creativecommons.org/licenses/by/4.0/.

\section{References}

Barton PS, Evans MJ, Foster CN, Cunningham SA, Manning AD (2017) Environmental and spatial drivers of spider diversity at contrasting microhabitats. Austral Ecol 42:700-710

Bellone D, Klapwijk MJ, Björkman C (2017) Habitat heterogeneity affects predation of European pine sawfly cocoons. Ecol Evol 7:11011-11020

Benton TG, Vickery JA, Wilson JD (2003) Farmland biodiversity: is habitat heterogeneity the key? Trends Ecol Evol 18:182-188

Brigić A, Bujan J, Alegro A, Šegota V, Ternjej I (2017) Spatial distribution of insect indicator taxa as a basis for peat bog conservation planning. Ecol Ind 80:344-353

Cazacu BC, Buzgar N, Iancu OG (2018) Geochemical and spatial distribution of heavy metals in forest soils adjacent to the tinovul mare poiana stampei peat bog. Rev Chim 69:434-438

Černecká L', Mihál I, Gajdoš P, Jarčuška B (2020) The effect of canopy openness of European beech (Fagus sylvatica) forests on grounddwelling spider communities. Insect Conserv Divers 13:250-261

Danu MA, Chifu T (2007) Contributions to the study of vegetation in Tinovul Mare (Poiana Stampei: district of Suceava). Buletinul Grădinii Botanice Iaşi 14:75-80

Danu MA, Irimia I (2009) Contributions to the study of vegetation in Tinovul Mare (Poiana Stampei: district of Suceava) (II). Sci Ann Danube Delta Inst 15:11-18

Docherty M, Leather SR (1997) Structure and abundance of arachnid communities in scots and lodgepole pine plantations. Forest Ecol Manage 95:197-207

Dufrêne M, Legendre P (1997) Species assemblages and indicator species: the need for a flexible asymmetrical approach. Ecol Monogr 67:345-366

Entling W, Schmidt MH, Bacher S, Brandl R, Nentwig W (2007) Niche properties of central European spiders: shading, moisture and the evolution of the habitat niche. Glob Ecol Biogeogr 16:440-448

Gajdos P, Majzlan O, Igondová E (2016) Assemblages of ground living spiders (Araneae) in Peatland habitats, surrounding dry pine forest and meadows. Folia Oecologica 43:147-155

Gallé R, Urák I (2002) Faunistical data on the spiders (Arachnida: Araneae) of the Nemira montain's bog complex with two new species for the Romanian fauna. Entomol Rom 7:85-88
Gallé R, Urák I (2006) Faunistical data on the spiders (Arachnida: Araneae) of the Lacul Dracului bog complex with new data for the Romanian fauna. Sci Ann Danube Delta Inst 12:29-32

Gallé R, Maák I, Szpisjak N (2014) The effects of habitat parameters and forest age on the ground dwelling spiders of lowland poplar forests (Hungary). J Insect Conserv 18:791-799

Gallé R, Gallé-Szpisjak N, Torma A (2017) Habitat structure influences the spider fauna of short-rotation poplar plantations more than forest age. Eur J Forest Res 136:51-58

Gallé R, Samu F, Zsigmond AR, Gallé-Szpisjak N, Urák I (2019) Even the smallest habitat patch matters: on the fauna of peat bogs. $J$ Insect Conserv 23:699-705

Gollan JR, Smith HM, Bulbert M, Donnelly AP, Wilkie L (2010) Using spider web types as a substitute for assessing web-building spider biodiversity and the success of habitat restoration. Biodivers Conserv 19:3141-3155

Haase H, Balkenhol B (2015) Spiders (Araneae) as subtle indicators for successional stages in peat bogs. Wetl Ecol Manag 23:453-466

Hsieh YL, Linsenmair KE (2011) Underestimated spider diversity in a temperate beech forest. Biodiver Conserv 20:2953-2965

Ingle K, Kaur H, Gallé-Szpisjak N, Bürgés J, Szabó Á, Gallé R (2020) Winter-active spider fauna is affected by plantation forest type. Environ Entomol 49:601-606

Joosten H, Clarke D (2002) Wise use of mires and Peatlands-background principles including a framework for decision-making. International Mire Conservation Group and International Peat Society, Saarijärvi, Finland, NHBS Ltd

Kajak A, Kupryjanowicz J, Petrov, P (2000) Long term changes in spider (Araneae) communities in natural and drained fens in the Biebrza River Valley. In: Gajdos P, Pekár S (eds) Proceedings of the 18th European colloquium of arachnology, Stará Lesná, 1999. Ekológia (Bratislava) vol 19, pp 55-64

Kamayev IO (2012) Spider (Aranei) assemblages in bog-forest ecotone of the northern taiga subzone (Eastern Fennoscandia). Entomol Rev 92:471-485

Koponen S (2004) Microhabitats of ground-living spiders in a peat bog. In: Samu F, Szinetár C (eds) Proceedings of the 20th European colloquium of arachnology, Szombathely 2002, European Arachnology (2002), pp 157-161

Kosulič O, Michalko R, Hula V (2016) Impact of canopy openness on spider communities: implications for conservation management of formerly coppiced oak forests. PLoS ONE 11:e0148585

Lindh BC, Muir PS (2004) Understory vegetation in young Douglas-fir forests: does thinning help restore old-growth composition? For Ecol Manag 192:285-296

McCoy ED, Bell SS (1991) Habitat structure: the evolution and diversification of a complex topic. In: Bell SS, McCoy ED, Mushinsky HR (eds) Habitat structure: the physical arrangement of objects in space. Chapman \& Hall, London, pp 3-27

Moreno G, Gonzalez-Bornay G, Pulido F, Lopez-Diaz ML, Bertomeu M, Juárez E, Diaz M (2016) Exploring the causes of high biodiversity of Iberian dehesas: the importance of wood pastures and marginal habitats. Agroforest Syst 90:87-105

Nentwig W, Blick T, Bosmans R, Gloor D, Hänggi A, Kropf C (2019) Araneae: spiders of Europe. Version 11.2019. https://www.arane ae.nmbe.ch. Accessed 10 Nov 2019

Nilsson C, Engelmark O, Cory J, Forsslund A, Carlborg E (2008) Differences in litter cover and understorey flora between stands of introduced lodge pole pine and native Scots pine in Sweden. For Ecol Manag 255:1900-1905

Ohlemüller R, Anderson BJ, Araújo MB, Butchart SH, Kudrna O, Ridgely RS, Thomas CD (2008) The coincidence of climatic and species rarity: high risk to small-range species from climate change. Biol Lett 4:568-572 
Oksanen J, Blanchet FG, Friendly M, Kindt R, Legendre P, McGlinn $\mathrm{D}$, et al (2016) vegan: community ecology package. R package version 2.4-3. R Foundation for Statistical Computing, Vienna

Oxbrough A, French V, Irwin S, Kelly TC, Smiddy P, O'Halloran J (2012) Can mixed species stands enhance arthropod diversity in plantation forests? Forest Ecol Manag 270:11-18

Řezáč M, Kůrka A, Růžička V, Heneberg P (2015) Red List of Czech spiders: adjusted according to evidence-based national conservation priorities. Biologia 70:645-666

Samu F, Urak I (2014) Are more bogs better? Comparative studies into Transylvanian peat bog spider (Arachnida: Araneae) assemblages from a conservation biological perspective. North West J Zool 10:94-101

Scott AG, Oxford GS, Selden PA (2006) Epigeic spiders as ecological indicators of conservation value for peat bogs. Biol Conserv 127:420-428

Šipoš J, Hédl R, Hula V, Chudomelová M, Košulič O, Niedobová J, Riedl V (2017) Patterns of functional diversity of two trophic groups after canopy thinning in an abandoned coppice. Folia Geobot 52:45-58

Sławska M, Bruckner A, Sławski M (2017) Edaphic Collembola assemblages of European temperate primeval forests gradually change along a forest-type gradient. Eur J Soil Biol 80:92-101

Spitzer K, Danks HV (2006) Insect biodiversity of boreal peat bogs. Annu Rev Entomol 51:137-161

Stańska M, Stański T, Gładzka A, Bartos M (2016) Spider Assemblages of hummocks and hollows in a primeval alder carr in the Białowieża national park - effect of vegetation structure and soil humidity. Pol J Ecol 64:564-577

Tews J, Brose U, Grimm V, Tielbörger K, Wichmann MC, Schwager M, Jeltsch F (2004) Animal species diversity driven by habitat heterogeneity/diversity: the importance of keystone structures. J Biogeogr 31:79-92

Urák I, Hartel T, Gallé R, Balog A (2017) Worldwide peatland degradations and the related carbon dioxide emissions: the importance of policy regulations. Environ Sci Policy 69:57-64

Van der Molen PC, Wijmstra TA (1994) The thermal regime of hummock-hollow complexes on Clara bog, co. Offaly Biol Environ 13:209-221

Vehviläinen H, Koricheva J, Ruohomäki K (2008) Effects of stand tree species composition and diversity on abundance of predatory arthropods. Oikos 117:935-943

Weiss I, Urák I (2000) Faunenlisten der Spinnen Rumäniens (Arachnida: Araneae). http://members.aol.com/Arachnologie/Faunenlist en.htm

Weng S, Kuo S, Guan BT, Chang T, Hsu H-W, Shen C-W (2007) Microclimatic responses to different thinning intensities in a Japanese cedar plantation of northern Taiwan. For Ecol Manag 241:91-100

Wise DH (1995) Spiders in ecological webs. Cambridge University Press, Cambridge

Ziesche TM, Roth M (2008) Influence of environmental parameters on small-scale distribution of soil-dwelling spiders in forests: What makes the difference, tree species or microhabitat? For Ecol Manag 255:738-752

Ziesche TM, Roth M (2013) Microhabitat heterogeneity in temperate forests: is distance to stems affecting ground-dwelling spider communities? Comm Ecol 14:8-17

Publisher's Note Springer Nature remains neutral with regard to jurisdictional claims in published maps and institutional affiliations. 